\title{
Tourism and Health Information System (THiS) in the Caribbean, June-September 2017
}

\author{
Jonathan Edwin*, Lisa Indar and Virginia Asin-Oostburg \\ Surveillance, Disease Prevention and Control Division, Caribbean Public Health Agency, Port of Spain, Trinidad and Tobago
}

\section{Objective}

The new Tourism and Health Information System (THiS) was implemented for syndromic surveillance in visitor accommodations in the Caribbean region. The objective was to monitor for illnesses and potential outbreaks in visitor accommodations (hotels/guest houses) in the Caribbean in real-time using the web-based application.

\section{Introduction}

Travel and tourism pose global health security risks via the introduction and spread of disease, as demonstrated by the H1N1 pandemic (2009), Chikungunya (2013), and recent Zika virus outbreak. In 2016, nearly 60 million persons visited the Caribbean. Historically no regional surveillance systems for illnesses in visitor populations existed. The Tourism and Health Information System (THiS), designed by the Caribbean Public Health Agency (CARPHA) from 2016-2017, is a new web-based application for syndromic surveillance in Caribbean accommodation settings, with real-time data analytics and aberration detection built in. Once an accommodation registers as part of the surveillance system, guests and staff can report their illness to front desk administration who then complete an online case questionnaire. Alternatively guests and staff from both registered and unregistered accommodations can self-report their illness using the online questionnaire in the THiS web application. Reported symptoms are applied against case definitions in real-time to generate the following syndromes: gastroenteritis, fever \& respiratory symptoms, fever \& haemorrhagic symptoms, fever \& neurologic symptoms, undifferentiated fever, and fever \& rash. Reported data is analyzed in real-time and displayed in a data analytic dashboard that is accessible to hotel/guest house management and surveillance officers at the Ministry of Health. Data analytics include syndrome trends over time, gender and age breakdown, and illness attack rates.

\section{Methods}

Visitor accommodations from the following countries participated: Bahamas, Barbados, Belize, Bermuda, Guyana, Jamaica, Trinidad \& Tobago, and Turks \& Caicos Islands. National staff from the Ministry of Health, Ministry of Tourism, and/or Tourism Authority/ Board engaged accommodations to participate. Participating accommodations were provided with training by national staff on how to report cases and use data analytic functions. They were asked to provide registration information to CARPHA, such as contact information to create login credentials, and data on occupancy rates for low/high seasons, number of staff, and number of lodging rooms to calculate illness attack rates. Weekly email reminders to accommodations to report cases of illness in the THiS web application, or to confirm 'nil' cases by email were sent by CARPHA staff.

\section{Results}

Of the 105 accommodations engaged by national staff, $39.1 \%$ $(\mathrm{n}=41)$ registered to participate, accounting for 3738 lodging rooms. From epidemiological week 24-39, five cases of syndromes from three accommodations in two countries were reported in the THiS web application (Table). A case of gastroenteritis and fever \& respiratory symptoms were self-reported from an unregistered accommodation. Three cases of gastroenteritis were reported by hotel administration from two registered accommodations. The average response rate to weekly emails confirming 'nil' cases was $32.1 \%$ (range: $10.5-83.3 \%$ ). One accommodation reported by email a cluster of 7 cases with possible conjuctivitis. No outbreaks or aberrations were detected in the THiS web application.

\section{Conclusions}

Engagement of Caribbean visitor accommodations in public health surveillance is a novel but critical undertaking for promoting health, safety, and security for both visitors and locals in the tourism dependent Caribbean region, but it will take time to establish. Confirming the absence of illness is an important public health endeavor for visitor accommodations. Preliminary results have demonstrated that it is possible for public health to work in a voluntary basis with the private accommodation sector. To establish more consistent and reliable reporting public health legislation and policies will need to be explored. As more data is gathered, assessments of the validity and sensitivity of the system will need to be conducted.

Syndromes Reported in the Tourism and Health Information System, JuneSeptember 2017

\begin{tabular}{|c|c|c|c|c|c|c|c|c|}
\hline Country & Hotel & $\begin{array}{c}\text { Epidemiological } \\
\text { Week }\end{array}$ & Syndrome & $\begin{array}{l}\text { No. of cases } \\
\text { (Atack Rate } \\
\% \text { ) }\end{array}$ & $\begin{array}{l}\text { Threshold } \\
\text { Reached for } \\
\text { Alert }\end{array}$ & $\begin{array}{l}\text { Guest or } \\
\text { Staff }\end{array}$ & $\begin{array}{c}\text { Age } \\
\text { Group }\end{array}$ & Gender \\
\hline \begin{tabular}{r|} 
Country \\
1
\end{tabular} & $\begin{array}{c}\text { Hotel } \\
\text { A }\end{array}$ & 32 & Gastroenteritis & $1(<2 \%)$ & No & Guest & 25--44 & Unknown \\
\hline $\begin{array}{r}\text { Country } \\
1\end{array}$ & $\begin{array}{c}\text { Hotel } \\
\text { A }\end{array}$ & 32 & $\begin{array}{l}\text { Fever \& Respiratory } \\
\text { Symptoms }\end{array}$ & 1 (n/a) & n/a & Guest & 25-44 | & Unknown \\
\hline $\begin{array}{c}\text { Country } \\
2\end{array}$ & $\begin{array}{c}\text { Hotel } \\
\text { B }\end{array}$ & 34 & Gastroenteritis & $1(<2 \%)$ & No & Guest & Unknown & Male \\
\hline $\begin{array}{r}\text { Country } \\
2\end{array}$ & $\begin{array}{c}\text { Hotel } \\
\mathrm{C}\end{array}$ & 35 & Gastroenteritis & $1(<2 \%)$ & No & Guest & Unknown & Male \\
\hline $\begin{array}{l}\text { Country } \\
2\end{array}$ & $\begin{array}{c}\text { Hotel } \\
\text { C }\end{array}$ & 35 & Gastroenteritis & $1(<2 \%)$ & No & Guest & Unknown & Unknown \\
\hline
\end{tabular}

Notes:

1. The threshold for gastroenteritis is an attack rate $\geq 2 \%$; for fever \& hemorrhagic, fever \& neurologic, and fever \& rash, the alert threshold is a single case.

2. Attack rate $\%$ calculation $=$ Number of cases $/[$ (number of rooms $x$ occupancy rate $\mathrm{x}$ average 2 persons per room) + number of staff]

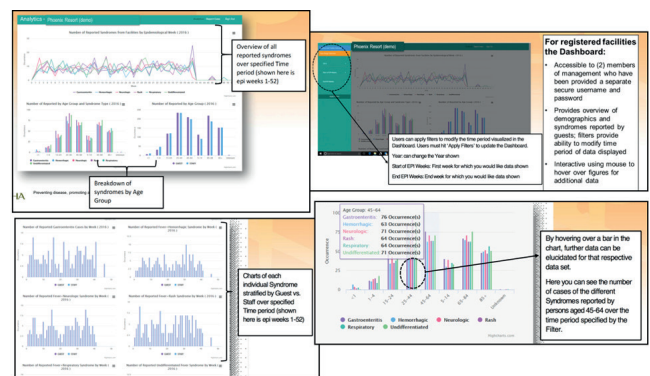

Figure. Snapshots from the THiS web application demonstrating data analytic functions, breakdown of syndromes by time and age (upper left), filters (upper right), individual

\section{Keywords}

Public Health Surveillance; Health Information Systems; Disease Outbreaks; Disease Notification; Travel

\section{*Jonathan Edwin}

E-mail: edwinjon@carpha.org 